\title{
SPATIAL TRANSFORMATIONS IN WORLD-HISTORICAL PERSPECTIVE
}

\section{Towards mapping the space and time of wealth accumulation}

\section{Roberto Patricio Korzeniewicz and Corey R. Payne}

\section{A world-historical perspective on spatial transformations}

The present moment is one of dramatic social change. The wave of "globalization" characterizing the world-system since the 1980s - as well as the movements against its harshest effects-have, in the words of the call for contributions to this volume, "manifest[ed] themselves in conflicting approaches to interpreting spaces, as the Charlottesville protests and the debate about whether nation states should have more (or less) open borders show" and have been "articulated in beliefs about security and insecurity, and in processes of closures, such as the rise in initiatives to build new border walls" (Knoblauch and Löw 2017a; cf. 2017b). Such reconfigurations are the guiding subject of this book.

In this chapter, we aim to provide a world-historical perspective to this ongoing discussion of spatial transformations. We are particularly interested in addressing a guiding hypothesis of the Collaborative Research Center on the "Re-Figuration of Spaces" (CRC 1265, Berlin, Germany):

The traditional, globally dominant model of modernity with its centralized nation states, borders and national economies conflicts with post- and latemodern transnationalization with its polycentrism, globalizing scope and breaking down of barriers. Our hypothesis is that spatial refiguration is a result of this tension.

(Knoblauch and Löw 2017a)

Thus, the CRC calls for

a conception of space that is no longer understood as-and simplistically reduced to - a fixed and homogeneous entity lying about somewhere out 
there calling for conquest or protection, but rather as a highly complex act of configuration.

(Knoblauch and Löw 2017a)

We argue that such reconfigurations of space are intimately intertwined with relocations in space- of labor, of capital, of production, of accumulation - that have long characterized historical capitalism. By briefly examining such spatial relocations in the modern world-system, this chapter seeks to contribute a world-historical perspective to the discussion on spatial transformations. In short, we argue:

(1) Examining spatial transformations of social relations requires a unit of analysis larger than the nation-state, no matter the time period we seek to understand

(2) Over time, spatial transformations have interacted with what Joseph Schumpeter calls "creative destruction," yielding spatial innovations

(3) The "local" and the "global" are not merely distinct spheres that are now in more complex interaction, but rather interacting, longue durée geographies of social and political contestation, cooperation, and identity-formation that, precisely as a consequence of their very interactions, have constantly undergone change

\section{The world-system as unit of analysis}

For the most part, the social sciences remain trapped in a familiar centuries-old paradigm wherein social interactions are constituted by, and constitutive of, individual nation-states. Perspectives that would otherwise differ across theoretical and methodological spectrums converge under this paradigm to understand social processes and social forces as the outcome or expression of interactions that take place primarily within national boundaries (e.g., class relations in versions emphasizing distributional struggles or, in others, emphasizing social integration, the particular solidarities produced by a growing division of labor).

Throughout the twentieth century, social scientists scrutinized individual national trajectories, particularly as they manifested themselves in the wealthiest countries of the world, to extrapolate generalizable patterns of economic, political, and social development. In the study of inequality, for example, modernization scholars predicted a growing gap between urban (largely industrial) and rural (largely agricultural) populations in the transition from traditional arrangements to modernity. Such a transition was the focus of much work on stratification, with the general expectation that modernization would bring about the displacement of ascription by achievement as the main criterion shaping social hierarchies. The withering away of ascription as a basis of social hierarchy, in turn, would both allow and require enhanced social mobility (e.g., from rural to urban areas, from agriculture into industry, from tradition to modernity).

More critical approaches argue that the trajectories of wealthy nations cannot be assumed to be independent from those of poor nations, or that the specific path 
of wealthy nations cannot be generalized into a universal model of social development that all nations are likely to follow. But while such critical perspectives have been productive in conceptualizing social inequality, stratification, and mobility in wealthy and poor nations as inter-relational, many versions of these critical perspectives have assumed or maintained their own unverified generalizations. Often, the assessment of world-systems perspectives, for example, has come to be reduced to the inclusion of a few variables in quantitative models, as if such perspectives can be reduced simply to the notion that high levels of wealth accumulation are secured to a much greater extent by manufacturing production rather than material production, by production for domestic consumption rather than by production for export, or by domestic rather than foreign investment.

In short, the mainstream social sciences by and large manage to hold on to the assumption that nation-states constitute the most relevant unit of analysis for the study of the social world. But nation-states are not always the appropriate unit for theorizing social relations.

We can use a foundational text of the modern social sciences, Adam Smith's The Wealth of Nations ([1776] 1976), to illustrate the importance of choosing an appropriate unit of analysis. In several passages of The Wealth of Nations, Smith discusses wealth disparities within and between town and countryside, in ways that echo discussions of such disparities within and between wealthy and poor nations today. Rather than following the existing common sense to explain the wealth of towns and the poverty of the countryside in the late eighteenth century as the outcome of processes occurring independently within each of these bounded territories, The Wealth of Nations chooses an alternative unit of analysis, one that encompasses both sets of spaces (town and countryside).

In Smith's account, the citizens of towns historically used corporate association to regulate production and trade in ways that restricted competition from the countryside - useful to contrast against the assumption that towns have been built primarily around inclusive practices.

The inhabitants of a town, being collected into one place, can easily combine together. The most insignificant trades carried on in towns have accordingly, in some place or another, been incorporated; and even where they have never been incorporated, yet the corporation spirit, the jealousy of strangers, the aversion to take apprentices, or to communicate the secret of their trade, generally prevail in them, and often teach them, by voluntary associations and agreements, to prevent that free competition which they cannot prohibit by byelaws.

(Smith [1776] 1976, I, 141)

As a result of such exclusionary arrangements, in their dealings with the countryside ("and in these latter dealings consists the whole trade which supports and enriches every town") town-dwellers were "great gainers" able to "purchase, with a smaller quantity of their labour, the produce of a greater quantity of the labour of 
the country" (Smith [1776] 1976, I, 139-140). In this account, the wealth of towns and the poverty of the countryside become inextricably linked, as it was largely to regulate and shape the flows (e.g., of goods, capital, and people) constituting this very relation that territorial boundaries between town and country were constructed and enforced.

While such arrangements tended to raise the wages that town employers had to pay,

in recompence, they were enabled to sell their own just as much dearer; so that so far it was as broad as long, as they say; and in the dealings of the different classes within the town with one another, none of them were losers by these regulations.

(Smith [1776] 1976, I, 139)

What Smith thereby describes is a process of selective exclusion. Through institutional arrangements establishing a social compact that restricted entry to markets, town-dwellers attained a virtuous combination of growth, political autonomy, and relative equity that simultaneously transferred competitive pressures to the countryside.

Adam Smith ([1776] 1976) provides important insights into the crucial role played by opportunity hoarding in shaping the relative prevalence of wealth and scarcity in town and countryside. But these insights would have been missed if his unit of analysis in The Wealth of Nations had failed to encompass both sets of spaces (towns and country) and their interaction in his narrative. For example, Smith could have attributed the wealth of towns to the individual effort, frugality, and/ or values of their citizens - thereby explaining the relative poverty of rural peoples as the consequence of insufficient achievement in each or any of these dimensions. But his account avoided such a naturalization of town/countryside boundaries and emphasized instead the relational processes (including the creation and enforcement of the boundaries demarcating "town" and "countryside") that in his account play a central role in explaining the uneven distribution of wealth across these spaces.

Like Smith, we find that the study of social relations most often requires a unit of analysis that is both global and historical - a perspective, moreover, that emphasizes the necessity of understanding these relations as embedded in space.

\section{Spatial "innovations" and Schumpeter's creative destruction"}

From a world-historical perspective, spatial transformations have been constant. Of course, the notion that "innovation" is at the heart of capitalist accumulation is deeply rooted in the social sciences and a central notion in the work of Adam Smith and Karl Marx. While Smith and Marx differed in explaining the sources of such innovation - the former emphasizing its dimensions as a response to competitive pressures, the latter focusing on the specificities of labor exploitation under capitalist production (with an emphasis on relative surplus) - they both emphasized 
innovation as a key outcome. This is why Joseph Schumpeter (1942, 82-3) emphasizes that, instead of a single transition from one state of equilibrium to another, we should conceive of capitalism as entailing continuous transformation:

Capitalism is by nature a form or method of economic change and not only never is but never can be stationary. The opening up of new markets, foreign or domestic, and the organizational development from the craft shop and factory to such concerns as U.S. Steel illustrate the same process of industrial mutation-if I may use that biological term-that incessantly revolutionizes the economic structure from within, incessantly destroying the old one, incessantly creating a new one. This process of Creative Destruction is the essential fact about capitalism. It is what capitalism consists in and what every capitalist concern has got to live in.

In the Schumpeterian model, the introduction and clustering of innovations disturb existing economic and social arrangements. Over time, this is the fundamental process driving cycles of prosperity (characterized by intense investment in new productive opportunities) and depression (characterized by the broader absorption of innovative practices and the elimination of older activities). We would contend it is also key to understanding changing opportunities for mobility and experiences of social upheaval, as embodied in waves of spatial relocation of economic activities. This argument is substantially similar to what Harvey (2001) and Silver (2003) describe as capital's "spatial fix."

The assortment of populations across the world into spatial territories is linked to processes of creative destruction. For the most part, the "wealthiest" within a key particular distributional array are constituted by those who are involved in the more "creative" end of the processes of creative destruction described by Schumpeter. Deskilling and the creation of the unskilled is precisely the outcome of constant "destruction," and processes of construction of categorical inequality are linked precisely to the criteria that are used at any given historical moment to assort populations into spaces that come to be denominated as "wealthy" and "poor," "skilled" and "unskilled," "civilized" and "barbarian." Historically, entry into privileged spaces has been constrained by the regulation of competition (e.g., as in the towns described by Adam Smith). We would argue that the use of ascriptive criteria to sort populations and thereby construct "space" (e.g., town and countryside, but also women and men, Black and white, poor nations and rich nations) has been, and continues to be, constitutive of the very creation and reproduction of inequality (see Korzeniewicz and Payne 2019 for a more detailed treatment of such processes).

Schumpeter (1942) purposefully did not restrict his notion of innovation to technological change or manufacturing. He emphasized that epicenters of wealth shifted constantly and are not associated with any single particular array of products, market networks, or institutional arrangements. New forms of raw material production, the capacity to engage in innovative forms of deploying territorial or 
political power, or even rent-seeking behaviors are just as likely to be a source of creation and destruction as any other innovation labeled by some as more "productive." Hand-in-hand with creative destruction, processes of exclusion in some spaces both led those excluded to seek better life chances elsewhere, and at times provided opportunities for the use of inclusion by rulers and elites elsewhere as a strategy to attract greater wealth. The pursuit of inclusion, in challenge to exclusionary practices, often was a driving force in the expansion of markets. In this sense, spatial reconfigurations-yielded by spatial relocations of economic activities - are an outcome of spatial innovations in accumulation.

\section{Blurred boundaries between the "local" and the "global"}

As noted by Giovanni Arrighi (1994, 4), in turn citing Fernand Braudel (1984),

the essential feature of historical capitalism over its longue durée - that is, over its entire lifetime - has been the "flexibility" and "eclecticism" of capital rather than the concrete forms assumed by the latter at different places and at different times.

In this sense, the association between wealth accumulation, industrial manufacturing, and particular geographical spaces that came to prevail in the nineteenth and twentieth centuries represented a "moment" in the development of the capitalist world-economy - a "particular input-output combination"-rather than its "true identity." Giovanni Arrighi $(2001,116)$ repeatedly emphasized that the constant mutation of world-economic processes generated difficulties for social science research:

Not only is the real home of capitalism a "shadowy zone." Not only is capitalism sometimes at home (as in the course of financial expansions) and sometimes away from home (as when it plunges massively into trade and production). On top of all of that, it becomes identified with states of ever-changing form and substance. No wonder that economic sociologists focusing on specific places and specific times find it hard to turn capitalism into a meaningful object of analysis.

Thus, transformations in patterns of wealth accumulation during the late nineteenth and twentieth centuries should be understood as a unique configuration of ongoing processes of creative destruction, just as much as the late twentieth and early twentyfirst centuries (or, for that matter, the sixteenth century itself) represent another unique configuration. This is perhaps another way of stating that "as the form of organization of the juxtaposed, spaces epitomize simultaneities" (Löw 2008, 25).

Constitutive of these patterns of change, there has been a recurrent tendency by those successful in business to firmly locate themselves in place and/or specific economic activities. For example, Korsch $(2014,228)$ indicates that 
the members of the Sceriman family who settled in Venice and Livorno followed the same economic strategies as the local upper classes: they had accumulated wealth through their trading activities, yet when profit margins from international commerce diminished they expanded their banking business and invested in property.

This was a general pattern, visible in all merchant communities, as illustrated by another example:

The wool trade had first brought the Castilians to Bruges, but in the midsixteenth century the members of the Castilian community were buying real estate and making other local investments. Such diversification served them well and reinforced their other local ties. As a consequence, the Castilian Consulado of Bruges lasted until the beginning of the eighteenth century, long after its initial raison d'etre, the wool trade, had ceased to be fundamental for its members' economic concerns.

(Phillips 1986, 48)

Genoa serves as another example of such relocations. The city-state had played an important role in the maritime European expansion of the sixteenth century "by seizing the opportunity for enormous gains through financing the empires of Charles V and Philip II” (Kirk 2005, 196). By the seventeenth century, Dutch and English merchants would become the ones to be on the ascendancy. Genoese financiers, moreover, while drawing significant profits from their activities, faced suspension of payments and/or bankruptcies by the Spanish Crown in 1575,1607 , and 1627, and by the late 1620s. Events such as these, and military reversals for Spain, came to be followed by gradual disinvestment-first from shipping and commercial activities, later from financing Spanish debt (Kirk 2005). Merchants and financiers came to see Dutch and English ships as providing more effective and secure protection than Genoese galleys. By the late 1650s, the main Genoese merchant companies (such as Compagnia di Nostra Signora di Libertá, the Compagnia Maritima di San Georgio, or the Compagnia delle Indie Orientali) found themselves "to be at a continual disadvantage with respect to the (by then) consolidated presence of the Dutch and, perhaps even more so, to the English" (Kirk 2005, 132). For Kirk (2005, 149), the decline of Genoa at sea demonstrated that its ruling class had become "very far removed from the reality of Liguria's seafaring men and from the day-to-day world of maritime commerce."

But, of course, locating themselves more firmly in place and/or specific economic activities made elites more exposed to potential obsolescence in ongoing processes of creative destruction. Just as in the case of black pepper and spices in the early sixteenth century, specific commodities and their chains of production, trade, and consumption were subject to shifting fortunes - and we have many contemporary examples (vide late twentieth century Detroit and its automobile industry) of 
such perilous outcomes. Thus, the ability to escape the constraints of obsolescence always has been unequally distributed across populations.

This is behind Pritchett's $(2006,5)$ "much less relentlessly happy story about the consequences of the proliferation of sovereigns and globalization of everything but labor." As geographic space is sliced into smaller nation-state units, some regions will experience large, persistent, positive shocks to labor demand and become "boom towns" with rapidly rising wages and incomes. But other regions may well experience large, persistent, negative, geographic-specific productivity shocks that reduce labor demand and lead to incipient "ghost countries." However, if outward labor mobility is limited, this will lead the adjustment to come not in changes in population but in wages, so countries will be "zombies"- the "living ghosts"with falling wages and incomes.

Perhaps the most useful instrument to escape such fixed rigidities, avoid obsolescence, and limit the potential of confiscation was the transformation of capital into its most liquid form: finance. Despite significant changes (e.g., money in the sixteenth century did not "look" the same as it would in the nineteenth century, nor did its networks of circulation and exchange), finance has remained, since the early days of historical capitalism, a key arena of apparent safety for capital avoiding rigid investments in space or activities.

To take an example. Ehrenberg's ([1928] 1963) detailed study of finance in the sixteenth and seventeenth centuries emphasizes that state-building and war-making efforts at the time were made possible by the "pure capital companies" developed by financiers in the Italian city-states and Southern Germany. Through their

concentration of great quantities of capital with individual intermediaries on the exchanges . . . these companies (in their earlier versions, the Bourses of the trade fairs), made large money amounts more available (for example, for rulers engaged in territorial expansion and/or preservation).

(Ehrenberg [1928] 1963, 376)

But the further expansion of such new financial and lending instruments, promoted substantially in the seventeenth century by the large capital needs of the companies seeking to capture "trade with the East Indies" (and, most notably, in the Amsterdam Chamber of the VOC), was key to overall capitalist development. Of course, Ehrenberg in 1928 is also trying to argue that speculation is part and parcel of the very character of financial and lending institutions.

In short, when taken from a transnational and historical perspective, it becomes clear that there has been a changing relevance of various kinds of territorial and institutional networks over the longue durée. Such variegated importance of networks, associations, cultural affiliations, and political containers challenges the often-prevailing emphasis on a gradual transition, characterized by the rise of towns, to a deepening divide between the urban and the rural in the rise and growing prevalence of national states, and an eruption of the global at the end of the twentieth century. Instead, we argue, the "local" and the "global" always have 
interacted in complex ways, both shaping (and given shape by) specific configurations of time and space. After all, "(s)pace makes action possible and is itself the field of action" (Löw 2008, 28), so space "can be seen as a relational ordering of living entities and social goods," and specific spaces are "products of action which at the same time have structuring power" (Löw 2008, 33-5). Likewise, flows have been as constitutive of space, as spaces have been constitutive of flows.

From a historical perspective, the spatial transformations taking place today, with the deindustrialization of the formerly prosperous areas of the mid-twentieth century and the rise in inequality in many wealthy countries, together with the populist right-wing challenge to globalization, can be seen as yet another iteration of conflict between practices of exclusion and practices of inclusion, over whether institutional arrangements (such as those embedded in national identities) should selectively continue to exclude the vast majority of the world population from access to opportunity.

\section{Conclusion}

This returns us to the three core arguments of this short chapter: First, no matter the time period we seek to understand, we should make sure to use an appropriate unit of analysis for the research through which we examine space and its transformations, and we argue for a world-historical perspective-understanding transnational geographies and longue durée evolutions-as a productive lens for examining the questions at hand.

Second, historically, waves of spatial transformation have interacted in fundamental ways with what Joseph Schumpeter calls "creative destruction"-for creative destruction always has entailed, simultaneously, both the opportunities of social mobility and the constraints of social dislocation, or, just as importantly, both social inclusion and social exclusion. Such spatial relocations of economic activities - or spatial innovations - are critical to understanding capitalism over its historical evolution.

Finally, from a world-historical perspective, the more "local" and the more "global" are not merely distinct spheres that only now are coming face-to-face in more complex interaction, but interacting geographies of social and political contestation, cooperation, and identity-formation that have always been present but, simultaneously and often as a consequence of their very interactions, are constantly undergoing change. Through the extension of networks and flows of rule and wealth, time and space become mutually redefined, changing the meaning of "place"- simultaneously at the most "local" and at the most "global," and intersecting with processes of inclusion, exclusion, and contestation.

These arguments, derived from past empirical work on the development of the capitalist world-system, point to the need for more rigorous future research on the links between the socioeconomic and the cultural-symbolic dimensions of spatial transformations. It may be that spatial reconfigurations are thus sparked by spatial innovations (in the Schumpeterian sense that we described earlier). Such matters 
require further investigation. For now, at least, it is clear that these processesreconfigurations of space and relocations in space-are intimately intertwined in the longue durée of the capitalist world-system.

\section{Note}

1 Several of the arguments in this section draw on previous work, such as Korzeniewicz and Moran (2009); Albrecht and Korzeniewicz (2014; 2017); and Korzeniewicz and Payne $(2019 ; 2020)$.

\section{References}

Albrecht, Scott, and Roberto Patricio Korzeniewicz. 2014. "Global Wages and World Inequality: The Impact of the Great Recession." In Structures of the World Political Economy and the Future Global Conflict and Cooperation (World Society Studies Volume 2014), edited by Christian Suter and Christopher Chase-Dunn, 33-52. Berlin: Lit.

Albrecht, Scott, and Roberto Patricio Korzeniewicz. 2017. "'Schöpferische Zerstörung' aus Perspektive des Weltsystems: Milliardäre und die große Rezession von 2008.” Zeitschrift für Weltgeschichte 18 (1): 79-108.

Arrighi, Giovanni. 1994. The Long Twentieth Century: Money, Power, and the Origins of Our Times. London: Verso.

Arrighi, Giovanni. 2001. "Braudel, Capitalism, and the New Economic Sociology." Review (Fernand Braudel Center) 24 (1). 107-123.

Braudel, Fernand. 1984. The Perspective of the World. New York: Harper \& Row.

Ehrenberg, Richard. (1928) 1963. Capital and Finance in the Age of the Renaissance: A Study of the Fuggers and their Connections. New York: Augustus M. Kelley.

Harvey, David. 2001. "Globalization and the Spatial Fix." Geographische Revue 2 (3): 23-31.

Kirk, Thomas A. 2005. Genoa and the Sea: Policy and Power in an Early Modern Maritime Republic, 1559-1684. Baltimore: The Johns Hopkins University Press.

Knoblauch, Hubert, and Martina Löw. 2017a. "TU Berlin: Spatial Analysis of Current Transformation Processes." Informationsdienst Wissenschaft (idw), December 6. https://idwonline.de/de/news685947.

Knoblauch, Hubert, and Martina Löw. 2017b. "On the Spatial Re-Figuration of the Social World.” Sociologica 11 (2): 1-27. doi: 10.2383/88197.

Korsch, Evelyn. 2014. "The Scerimans and Cross-Cultural Trade in Gems: The Armenian Diaspora in Venice and its Trading Networks in the First Half of the Eighteenth Century." In Perspectives in Economic and Social History: Commercial Networks and European Cities, 1400-1800, edited by A. Caracausi and C. Jeggle, 223-239. London: Pickering \& Chatto Publishers.

Korzeniewicz, Roberto Patricio, and Timothy Patrick Moran. 2009. Unveiling Inequality. New York: Russell Sage Foundation.

Korzeniewicz, Roberto Patricio, and Corey R. Payne. 2019. "Sugar, Slavery, and Creative Destruction: World-Magnates and 'Coreification' in the Longue-Durée." Journal of World-Systems Research 25 (2): 395-419.

Korzeniewicz, Roberto Patricio, and Corey R. Payne. 2020. "Rethinking Core and Periphery in Historical Capitalism: World-Magnates and The Shifting Epicenters of Wealth Accumulation." In Economic Cycles and Social Movements: Past, Present and Future, edited by Eric Mielants and Katsiaryna Salavei Bardos. London: Routledge. 
Löw, Martina. 2008. "The Constitution of Space: The Structuration of Spaces Through the Simultaneity of Effect and Perception." European Journal of Social Theory 11 (1): 25-49.

Phillips, William D., Jr. 1986. "Local Integration and Long-Distance Ties: The Castilian Community in Sixteenth-Century Bruges." The Sixteenth Century Journal 17 (1): 33-49.

Pritchett, Lant. 2006. "Boom Towns and Ghost Countries: Geography, Agglomeration, and Population Mobility." Brookings Trade Forum 2006: 1-42. doi: 10.1353/btf.2007.0009.

Schumpeter, Joseph. 1942. Capitalism, Socialism and Democracy. New York: Harper and Row. Silver, Beverly J. 2003. Forces of Labor: Workers' Movements and Globalization since 1870. Cambridge: Cambridge University Press.

Smith, Adam. (1776) 1976. An Inquiry into the Nature and Causes of The Wealth of Nations. Chicago: The University of Chicago Press. 